Article

\title{
Evaluation of a Keratin 1 Targeting Peptide-Doxorubicin Conjugate in a Mouse Model of Triple-Negative Breast Cancer
}

\author{
Azam Saghaeidehkordi ${ }^{1}$, Shiuan Chen ${ }^{2} \mathbb{D}$, Sun Yang $^{1}$ and Kamaljit Kaur ${ }^{1, *(D)}$ \\ 1 Chapman University School of Pharmacy (CUSP), Harry and Diane Rinker Health Science Campus, \\ Chapman University, Irvine, CA 92618-1908, USA; sagha102@mail.chapman.edu (A.S.); \\ syang@chapman.edu (S.Y.) \\ 2 Department of Cancer Biology, Beckman Research Institute of the City of Hope, Duarte, CA 91010, USA \\ SChen@coh.org \\ * Correspondence: kkaur@chapman.edu; Tel.: +714-516-5494; Fax: +714-516-5481
}

Citation: Saghaeidehkordi, A.; Chen, S.; Yang, S.; Kaur, K. Evaluation of a Keratin 1 Targeting Peptide-

Doxorubicin Conjugate in a Mouse Model of Triple-Negative Breast Cancer. Pharmaceutics 2021, 13, 661. https://doi.org/10.3390/

pharmaceutics13050661

Academic Editor: Christopher Scott

Received: 28 March 2021

Accepted: 30 April 2021

Published: 5 May 2021

Publisher's Note: MDPI stays neutral with regard to jurisdictional claims in published maps and institutional affiliations.

Copyright: (c) 2021 by the authors. Licensee MDPI, Basel, Switzerland. This article is an open access article distributed under the terms and conditions of the Creative Commons Attribution (CC BY) license (https:// creativecommons.org/licenses/by/ $4.0 /)$.

\begin{abstract}
Chemotherapy is the main treatment for triple-negative breast cancer (TNBC), a subtype of breast cancer that is aggressive with a poor prognosis. While chemotherapeutics are potent, these agents lack specificity and are equally toxic to cancer and nonmalignant cells and tissues. Targeted therapies for TNBC treatment could lead to more safe and efficacious drugs. We previously engineered a breast cancer cell targeting peptide 18-4 that specifically binds cell surface receptor keratin 1 (K1) on breast cancer cells. A conjugate of peptide 18-4 and doxorubicin (Dox) containing an acid-sensitive hydrazone linker showed specific toxicity toward TNBC cells. Here, we report the in vivo evaluation of the K1 targeting peptide-Dox conjugate (PDC) in a TNBC cell-derived xenograft mouse model. Mice treated with the conjugate show significantly improved antitumor efficacy and reduced off-target toxicity compared to mice treated with Dox or saline. After six weekly treatments, on day 35, the mice treated with PDC (2.5 mg Dox equivalent $/ \mathrm{kg}$ ) showed significant reduction (1.5 times) in tumor volume compared to mice treated with Dox $(2.5 \mathrm{mg} / \mathrm{kg})$. The mice treated with the conjugate showed significantly higher (1.4 times) levels of Dox in tumors and lower (1.3-2.2 times) levels of Dox in other organs compared to mice treated with Dox. Blood collected at 15 min showed 3.6 times higher concentration of the drug (PDC and Dox) in mice injected with PDC compared to the drug (Dox) in mice injected with Dox. The study shows that the K1 targeting PDC is a promising novel modality for treatment of TNBC, with a favorable safety profile, and warrants further investigation of $\mathrm{K} 1$ targeting conjugates as TNBC therapeutics.
\end{abstract}

Keywords: triple-negative breast cancer; peptide-drug conjugate or peptide-doxorubicin conjugate; keratin 1 targeting; cell-derived xenograft; antitumor efficacy; off-target toxicity

\section{Introduction}

Triple-negative breast cancer (TNBC) is an important subtype of breast cancer as it is aggressive and has a poor prognosis [1,2]. TNBC is characterized by the absence of estrogen and progesterone receptors and without the overexpression of human epidermal growth factor receptor 2 (HER2). TNBC is a heterogeneous disease with $\approx 80 \%$ of TNBC cells with basal-like gene expression characteristics, such as KRT5, KRT14, KRT17, and EGFR [1,3]. Lehmann et al. defined TNBC into four molecular subtypes, namely basal-like 1 (BL1), basal-like 2 (BL2), mesenchymal (M) and, luminal androgen receptor (LAR) [3]. Several potential pathways with deletion (such as PTEN) and mutation/amplification (PIK3CA, $K R A S, B R A F, E G F R$, and MET) of genes have been identified as druggable molecular alterations in TNBC, but these have not proven to be clinically successful yet [1]. Some success has been seen with the recent approval of poly-ADP ribose-polymerase (PARP) and immune directed checkpoint inhibitors, and an antibody-drug conjugate, sacituzumab govitecan [4]. 
Chemotherapy remains the primary treatment for TNBC [5]. Anthracyclines alone or sequential treatment with anthracycline, cyclophosphamide, and taxane are used to achieve pathological complete response (pCR) in patients. The benefit of dose-dense (weekly or once every 2 weeks) administration of chemotherapeutics to achieve the highest $\mathrm{pCR}$ rates is also emphasized [6]. However, chemotherapy's effectiveness is limited due to two reasons: (i) intolerable toxicities that emerge after intensive therapy as a result of nonspecific action of the chemotherapeutics in healthy tissues, and (ii) the inherent or acquired resistance of tumor cells to chemotherapeutics that leads to selection and proliferation of resistant cells after first-line treatment. Overall, this leads to poor quality of life in patients and forces the clinicians to use suboptimal doses of the drug to prevent both acute and chronic toxicities. In addition, the resistance of tumor cells to chemotherapeutics increases the chance of survival of migrated tumor cells and progression to fatal metastasis [7].

Different strategies are being developed to target chemotherapeutic agents to improve their specific uptake by cancerous cells in tumors, such as the use of targeting ligands to target specific receptors on cancer cells [8-10]. Active targeting of the drug with targeting ligands, like engineered antibodies or tumor homing peptides, allows a higher concentration of the drug to reach the tumor site, thereby increasing efficacy and reducing toxic side effects of the drug [8-10]. A drug conjugated to an antibody or a peptide via a linker yields an antibody-drug conjugate (ADC) or a peptide-drug conjugate (PDC). ADC and PDC are new modalities that show promise in the treatment of various cancers $[8,9,11]$. In recent years, several ADCs have been FDA approved to treat hematologic and solid cancers [9,12]. ADCs and PDCs in the clinical and preclinical development lay promise for the future of this rapidly growing class of drugs in oncology. ADC sacituzumab govitecan was FDA approved for the treatment of metastatic TNBC, where the antibody targets trophoblast cell-surface antigen 2 (Trop-2) present on TNBC cells [12-14]. Erythropoietin-producing hepatocellular receptor A2 (EphA2) is a protein from the receptor tyrosine kinase family that serves as a known target for cancer treatment due to its overexpression in tumors and low expression in healthy tissues $[15,16]$. EphA2 is being utilized for the development of targeted therapies such as ADCs and PDCs [8,17-19]. Similarly, several other receptors, such as gonadotropin-releasing hormone (GnRH), LDL receptor-related protein 1 (LRP1), somatostatin subtype-2, and transferrin, are being targeted for delivery of chemotherapeutics to the cancer site [8]. A PDC (ANG1005) of paclitaxel with an LRP1 targeting peptide angiopep- 2 is currently undergoing several clinical trials for the treatment of patients with brain metastases from breast cancer [20-22].

Keratin $1(\mathrm{~K} 1)$ is a novel receptor, present on the surface of cancer cells (breast and neuroblastoma) [23-25] and cells that have undergone oxidative stress [26], that is being used for targeted drug delivery. We showed that K1 is present on the surface of MCF-7 breast cancer cells, and a comparison of the total $\mathrm{K} 1$ levels in cell lysates using Western blot showed that cancer cells (MCF-7 and MDA-MB-435) have a much higher expression of $\mathrm{K} 1$ compared to non-cancerous breast tissue derived epithelial (MCF-10A) cells [25]. We engineered peptides, such as linear 18-4 and cyclic analogues, for specific uptake by breast cancer cells (MCF-7 and MDA-MB-231) via cell surface K1 mediated endocytosis [25,27]. Further, K1 targeting linear peptide 18-4 was used to synthesize four peptide-doxorubicin conjugates with different linker chemistries, such as ester, amide, succinimidyl thioether, and hydrazone [28,29]. We showed specific uptake of the targeted PDCs via receptor mediated endocytosis in MCF-7 and MDA-MB-435-MDR cancer cells [28]. The PDCs with $\mathrm{K} 1$ targeting peptide 18-4 were more cytotoxic to TNBC cells $\left(\mathrm{IC}_{50} 1.2-4.7 \mu \mathrm{M}\right)$ compared to non-cancerous human mammary epithelial MCF-10A cells ( $\mathrm{IC}_{50} 15.1-38.6 \mu \mathrm{M}$ ), while free drug (doxorubicin) was equally cytotoxic to both cancer and non-cancerous cells $\left(\mathrm{IC}_{50} 0.24-1.5 \mu \mathrm{M}\right)$ [29]. To explore the in vivo efficacy and evaluate the potential of $\mathrm{K} 1$ targeting PDC for TNBC treatment, we report here the antitumor activity of one of these peptide-doxorubicin conjugates (Figure 1), where the peptide (18-4) is conjugated to Dox via an acid-sensitive $\mathrm{N}$-acyl hydrazone linker in a mouse model for TNBC. TNBC MDAMB-231 cells were subcutaneously injected into female NOD/SCID mice to generate TNBC 
cell-derived xenograft models. Mice treated with the conjugate showed better efficacy, pharmacokinetics, and safety profile compared to the Dox treated mice, supporting the future clinical development of K1 targeted PDCs for treatment of TNBC.

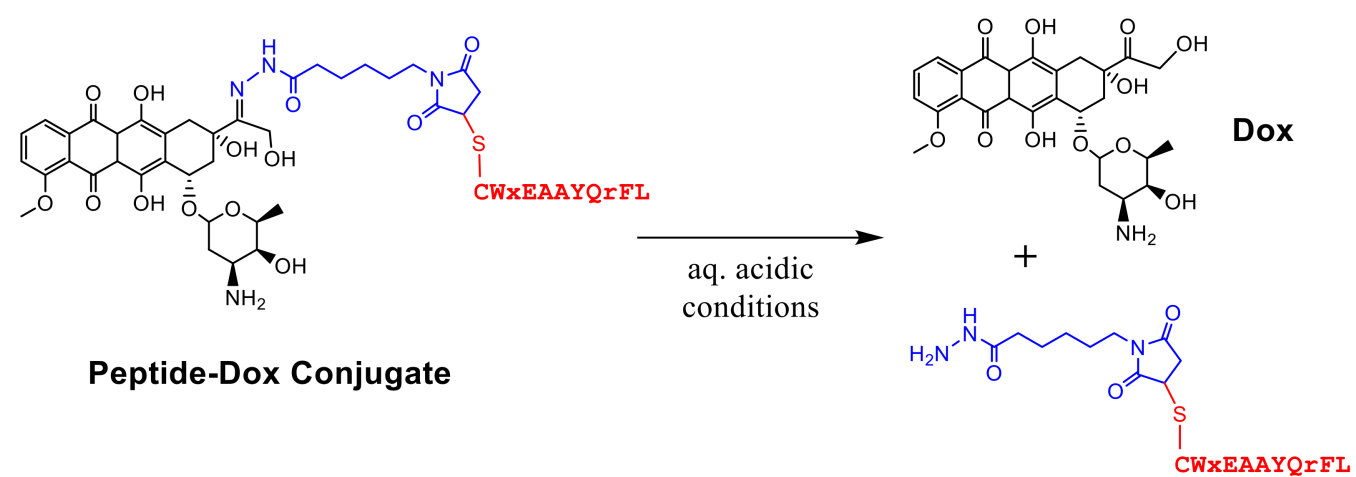

Figure 1. Structure of keratin 1 targeting peptide-Dox conjugate (PDC). The conjugate contains an $\mathrm{N}$-acyl hydrazone linker which hydrolyzes under aqueous acidic conditions to give unmodified doxorubicin (Dox) and hydrazide linker with the peptide. Peptide, linker, and Dox are shown in red, blue, and black, respectively.

\section{Materials and Methods}

\subsection{Conjugate Solution for Intravenous Injections}

Peptide-Dox conjugate (PDC, Figure 1) was synthesized and purified, as described previously [29]. Doxorubicin hydrochloride salt (Dox.HCl) was purchased from LC Laboratories (Woburn, MA, USA), while daunorubicin hydrochloride (Dau) and aldoxorubicin (Aldox) were from MedChem Express (Monmouth Junction, NJ, USA). An analytical reversed-phase high performance liquid chromatography (RP-HPLC) column $(4.6 \mathrm{~mm} \times 250 \mathrm{~mm}, 5 \mu \mathrm{m})$ running with a gradient on a Shimadzu LCMS 2020 (Shimadzu Corporation, Columbia, MD, USA) was used for characterization of PDC. The mass spectrum showed two m/z peaks, $717.5(3+)$ and $1075.2(2+)$, for the conjugate that allowed found mass to be 2149.5 (calculated mass 2148.7) [30]. The UV/Vis spectra for all compounds $(\approx 200 \mu \mathrm{M})$ were obtained on UV/Vis spectrophotometer UV-2600/2700 (Shimadzu Corporation, MD, USA). Stock solutions of Dox and conjugate were prepared in $0.9 \%$ sterile saline (MWI Animal Health, Boise, ID, USA) and concentration was measured using QuickDrop (Molecular Devices, San Jose, CA, USA) at $481 \mathrm{~nm}$ and $495 \mathrm{~nm}$, respectively. The stock solution was diluted to the appropriate concentration ( $2.5 \mathrm{mg}$ Dox or Dox equivalent $/ \mathrm{kg}$ ) in $0.9 \%$ saline solution before injecting. Solutions were prepared fresh or a few days before each injection and kept at $-20^{\circ} \mathrm{C}$ freezer until use. All solutions were warmed $\left(30-32{ }^{\circ} \mathrm{C}\right)$ prior to injection, and each mouse was intravenously injected with $200 \mu \mathrm{L}$ solution via tail vein.

\subsection{Drug Circulation Time}

Nonobese diabetic - severe combined immunodeficiency (NOD-SCID) female mice (8-week old) were purchased from Charles River Laboratories (Wilmington, MA, USA). All animal experiments were performed according to the Chapman University Institutional Animal Care and Use Committee (protocol \# 1617A008, approval period 16 May 201715 May 2020 and protocol \# 2020-1148, approval period 20 May 2020-20 May 2023) and in accordance with NIH guidelines. To measure the circulating levels of the drug, after intravenous administration of PDC ( $2.5 \mathrm{mg}$ Dox equivalent $/ \mathrm{kg}$ ) via tail vein, mice $(n=3)$ were euthanized using metered $\mathrm{CO}_{2}$ gas chamber at times $0.25,2,4$, and $24 \mathrm{~h}$. The blood samples were collected via cardiac puncture and kept at room temperature for $30 \mathrm{~min}$ until the blood coagulated [31]. Serum samples were then collected by centrifuging at $3000 \times g$ for $15 \mathrm{~min}$ at room temperature. With the size of mice that were used for the study, cardiac puncture collected at least $250 \mu \mathrm{L}$ of whole blood, which approximately yielded 
$100 \mu \mathrm{L}$ of serum. The conjugate and its metabolite were extracted from serum following the previous method with some modifications [32,33]. Briefly, the serum was diluted with MQ water $(300 \mu \mathrm{L})$ and mixed with acetonitrile $(300 \mu \mathrm{L})$. Daunorubicin $(20 \mu \mathrm{L}$ and $150 \mu \mathrm{M})$ was added as an internal standard to each sample before organic extraction. The resulting mixture was vortexed for $20 \mathrm{~s}$. It was then centrifuged at $2500 \times g$ for $3 \mathrm{~min}$. The supernatant was transferred to a new tube containing $1 \mathrm{~mL}$ of MQ water. Next, chloroform and isopropanol mixture $(4 \mathrm{~mL}, 1: 1)$ was added, followed by vortex-mixing for $60 \mathrm{~s}$. After centrifugation for $3 \mathrm{~min}$ at $2500 \times g$, the organic lower layer needed to remain in the tube, and the top layer was carefully removed and discarded. The content in the tube was then dried using SpeedVac Concentrator (Thermo Scientific SPD1010, Waltham, IL, USA), followed by reconstitution in methanol $(120 \mu \mathrm{L})$. An aliquot $(40 \mu \mathrm{L})$ was injected into an analytical RP-HPLC column and analyzed using LC/MS. A gradient method was used to elute and characterize the conjugate and its metabolites.

\subsection{Cell Culture and Tumor Inoculation}

Human TNBC MDA-MB-231 cells were purchased from the American Type Culture Collection (ATCC, Manassas, VA, USA). Cells were cultured in DMEM/F12 media (Gibco, New York, NY, USA), supplemented with 10\% FBS (Corning) and 1\% penicillin/streptomycin (Gibco, NY, USA). Cells were kept in a humidified atmosphere in a 5\% $\mathrm{CO}_{2}$ incubator maintained at $37^{\circ} \mathrm{C}$. Twenty-one NOD-SCID female mice were used for tumor inoculation. Each mouse (8-week old) was inoculated with 2 million MDA-MB-231 cells in DMEM-F12 media/Matrigel (1:1 ratio, $100 \mu \mathrm{L})$ (Corning, Glendale, AZ, USA) by subcutaneous injection into the right flank using $1 \mathrm{~mL}$ conjugate syringes and $25 \mathrm{G}$ needles to prevent destruction of cells [32]. The needle was slightly twisted outwards to avoid the content from leaking out. Tumor size was measured twice weekly with a digital caliper in two dimensions (length: largest diameter, width: smaller diameter) and tumor volume was calculated using the formula: $\frac{3}{4} \pi \times \mathrm{L} \times \mathrm{W}^{2} \times 1 / 8\left(\mathrm{~mm}^{3}\right)(\mathrm{L}=$ length; $\mathrm{W}=$ width; $\mathrm{mm})$ [34].

\subsection{Drug Treatment}

After inoculation, when the volumes of MDA-MB-231 tumor xenografts reached around $100-150 \mathrm{~mm}^{3}$, mice were randomly divided into three groups for the experimental treatment. The general health status of each mouse was monitored daily for any signs of distress, such as lethargy, ruffled coat, and ataxia. Body weight was also recorded weekly to assess systemic toxicity associated with the treatments. The mice were subjected to euthanasia if (1) the mouse's body weight dropped below $15 \%$ of its initial weight, (2) the mouse's tumor became $>1.5 \mathrm{~cm}$ across in any dimension, or (3) the mouse became lethargic, sick, or unable to feed. Twenty-one mice divided into three groups $(n=7)$ were treated with (i) $0.9 \%$ saline solution containing 3\% DMSO (treatment group 1), (ii) free Dox ( $2.5 \mathrm{mg} / \mathrm{kg}$ body weight) (treatment group 2), or (iii) peptide-Dox conjugate (2.5 mg DOX equivalent $/ \mathrm{kg}$ ) (treatment group 3). All treatments in $0.9 \%$ saline solution containing $3 \%$ DMSO were administered intravenously via tail vein $(200 \mu \mathrm{L})$ every 7 th day for a total of six doses. Tumor size was measured twice weekly on the day of injection and three days later. Saline treated mice were euthanized earlier than the DOX or conjugate treated mice (day 32 instead of day 36) due to the large tumor size (volume $\approx 800 \mathrm{~mm}^{3}$ ) and difficulty in moving and feeding, which is compliant with the euthanasia criteria.

\subsection{Biodistribution of Drug}

For the biodistribution analysis of PDC, mice were euthanized $24 \mathrm{~h}$ after the last dose. The tumor xenografts and other tissues/organs (liver, spleen, kidneys, lungs, and heart) were collected from each mouse, and stored at $-80{ }^{\circ} \mathrm{C}$ for Dox and/or metabolite analysis using LC/MS. Tumors were weighed individually to obtain the average tumor weight for each treatment group. For extraction of Dox and its metabolites from the tissue samples, the samples were thawed, and $100 \mathrm{mg}$ of tissue was homogenized in MQ water 
$(300 \mu \mathrm{L})$ using a tissue grinder (BTLab Systems, Saint Louis, MO, USA) [32,33]. The Dox and its metabolites were extracted from the tissue samples as described above for the serum samples. The extracted sample was reconstituted in methanol $(120 \mu \mathrm{L})$ and centrifuged to collect the supernatant. This was done to remove any insoluble particulates and prevent clogging the RP-HPLC column. The supernatant $(40 \mu \mathrm{L})$ was injected into an analytical RP-HPLC column and analyzed using Shimadzu LCMS 2020 presented as $\mu \mathrm{g} / \mathrm{g}$ tissue.

\subsection{Statistical Analysis}

Data are presented as mean \pm standard deviation (SD), and statistical significance of difference was assessed using Student's $t$-test and one-way analysis of variance (ANOVA) test. The difference was considered statistically significant with $p<0.05$ and the reported $p$ values were from two-tailed tests. All data that required non-linear regression analysis were processed using Microsoft Office Excel or GraphPad Prism, version 9.0.0 (GraphPad software, San Diego, CA, USA).

\section{Results}

\subsection{In Vivo Stability of Peptide-Dox Conjugate}

A gradient method was developed to observe and characterize the PDC (Figure 1) and its metabolites using the LC/MS. An analytical RP-HPLC column running with a $15-55 \%$ acetonitrile/water gradient (with $0.05 \%$ formic acid) over $41.5 \mathrm{~min}$ at a flow rate of $0.4 \mathrm{~mL} / \mathrm{min}$ was used. As shown in Figure S1 (Supplementary Materials), this method eluted the PDC as three overlapping peaks on the analytical column between 32.8-36.0 min. The eluting peaks were monitored using UV-vis at $481 \mathrm{~nm}$ and electrospray mass spectra. The mol. wt. for each of the peaks calculated from the electrospray mass spectra was found to be 2149.5 (calculated 2148.7). The three peaks with the same molecular weight likely represent three solution conformations of the conjugate. The UV-Vis spectrum for the conjugate solution $(\approx 200 \mu \mathrm{M})$ was compared to the spectra for Aldox and Dox. It was found that the conjugate displayed similar broad maxima as observed for Aldox and Dox around 480-495 nm (Figure S2).

In the design of the PDC, the Dox and peptide were linked via an N-acyl hydrazone bond on one end and a succinimide thioether bond at the other end (Figure 1). While thioether is considered non-cleavable, the acid-sensitive hydrazone was incorporated to facilitate the release of the unmodified drug at the target tumor site, i.e., in the tumor microenvironment or after the cellular uptake in the acidic environment of endosomes or lysosomes [8]. To evaluate the circulation time of the drug after systemic administration of PDC, the PDC (2.5 mg Dox equivalent $/ \mathrm{kg}$ ) was injected intravenously via the tail vein in mice. Blood samples were collected via cardiac puncture at different time intervals. PDC and its metabolites were extracted following a series of steps and analyzed using LC/MS (Figure 2). At 15 min after PDC injection, the PDC and Dox were detected in blood serum. At $2 \mathrm{~h}$, both were still present; however, the concentration for each dropped substantially $(2.3 \times$ less PDC and $1.8 \times$ less Dox) compared to at $15 \mathrm{~min}$ (Figure $2 \mathrm{a}, \mathrm{c})$. At $4 \mathrm{~h}$ after injection, only Dox was observed. By $24 \mathrm{~h}$ after injection, Dox diminished to an undetectable level in the blood. Based on the total concentration of the drug (PDC and Dox) present in the blood, the circulation half-life of the drug (PDC and Dox) was estimated as $\approx 1.7 \mathrm{~h}$ after PDC administration. This is substantially longer than Dox's half-life, which was eliminated from the blood within minutes after Dox injection [35]. We observed that mice injected with PDC had 3.6 times more drug $(227.5 \pm 15 \mu \mathrm{M})$ in blood compared to drug levels $(63.4 \pm 4.2 \mu \mathrm{M})$ in mice injected with free Dox at $15 \mathrm{~min}$ (Table S1 and Figure S3). The results demonstrate higher concentration and a longer circulation time of the drug (PDC and Dox) after PDC administration (2.5 mg Dox equivalent $/ \mathrm{kg}$ ) compared to the drug (Dox) after Dox administration $(2.5 \mathrm{mg}$ Dox $/ \mathrm{kg}$ ) to mice. Here, the total drug concentration (PDC and Dox) in the blood was determined after PDC administration, as the experiment does not allow estimation of PDC alone in blood. This is because PDC was likely hydrolyzed to Dox while blood was being processed by different steps, such as blood coagulation, 
centrifugation, and extraction. This is also the likely reason for a large Dox peak and a small PDC peak at $15 \mathrm{~min}$ (Figure 2a) and does not reflect the true ratio of the two in blood at $15 \mathrm{~min}$.

(a)

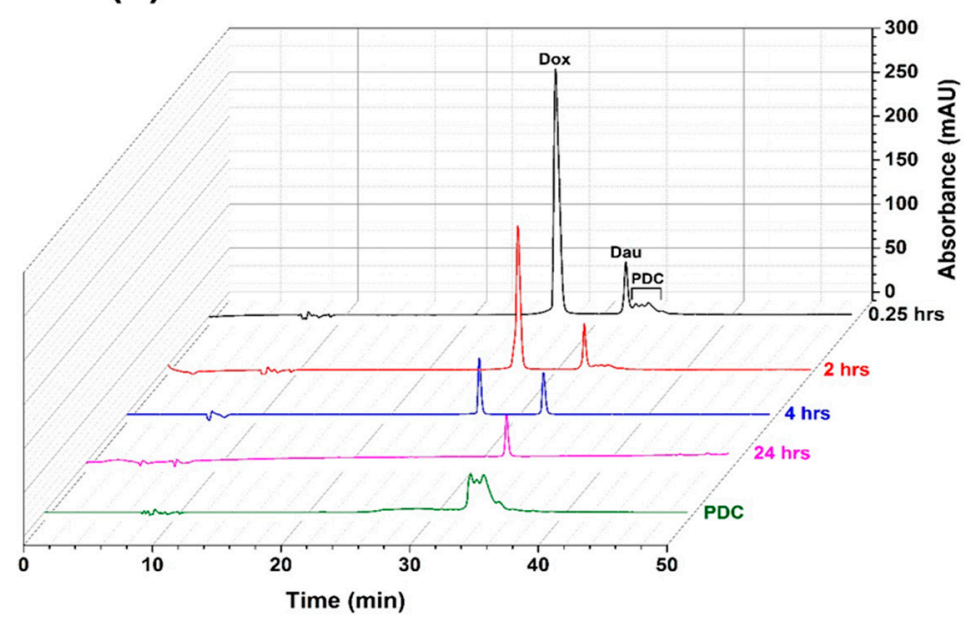

(c)

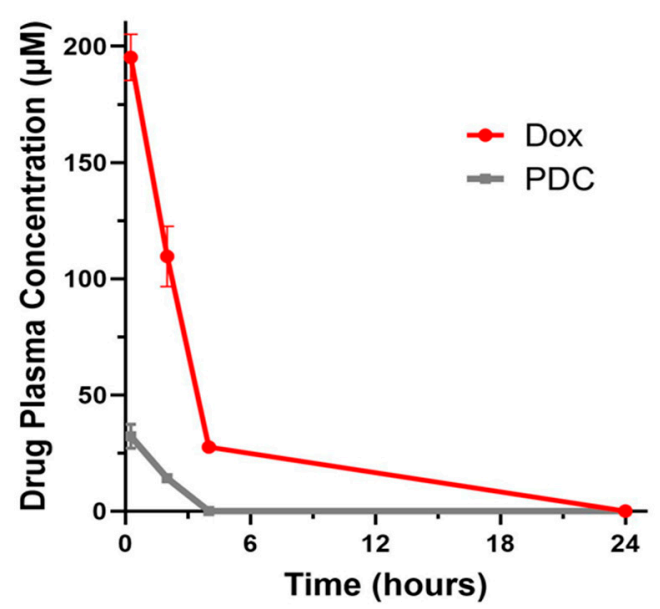

(b)
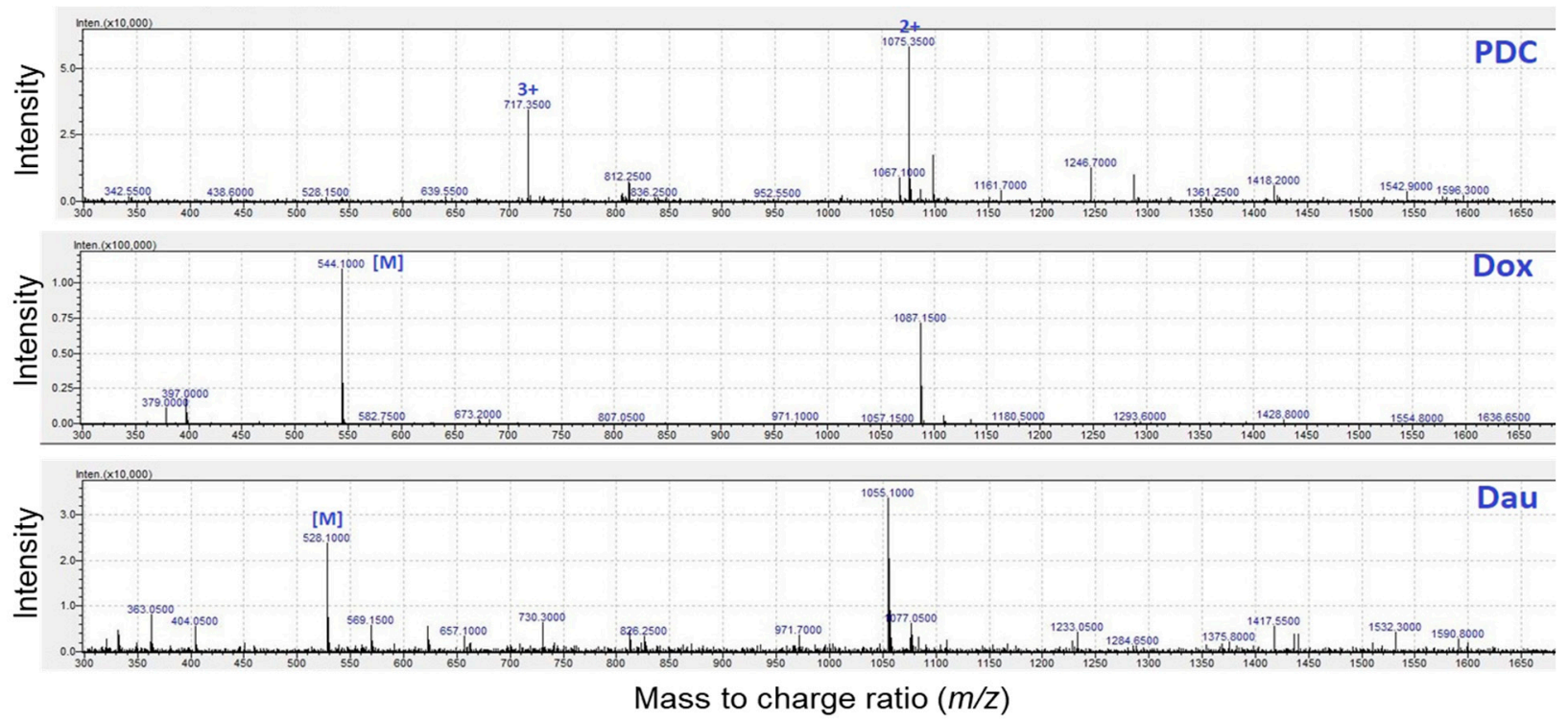

Figure 2. Concentration of total drug (PDC and Dox) after administration of PDC in female (8-week-old) nonobese diabeticsevere combined immunodeficiency (NOD-SCID) mice. Mice $(n=3)$ were administrated PDC $(2.5 \mathrm{mg} / \mathrm{kg}$ Dox equivalent or $0.088 \pm 0.008 \mu$ moles) via tail vein injection, and blood was collected via cardiac puncture at $0.25,2,4$, and $24 \mathrm{~h}$. The serum $(100 \mu \mathrm{L})$ from blood was collected. Serum was subjected to organic extraction, and the extract was injected in LC/MS system to detect and quantify PDC and released Dox. No other metabolites of Dox were observed. (a) Representative chromatograms for samples after extraction, monitored at $\lambda=481 \mathrm{~nm}$. Dau was used as an internal standard. Chromatogram of pure PDC $(280 \mu \mathrm{M}, 20 \mu \mathrm{L})$ is shown for comparison; (b) Representative electrospray ionization (ESI) mass spectra of PDC, Dox, and Dau obtained during the LC/MS analysis of one sample out of three at $0.25 \mathrm{~min}$. PDC shows two $\mathrm{m} / \mathrm{z}$ peaks at 717.35 and 1075.35 with charges +3 and +2 , respectively. The found mass (M) from these peaks for PDC was 2149.1 (calcd. 2148.7). For Dox and Dau, the found mass were 544.1 (calcd. 543.5) and 528.1 (calcd. 527.5), respectively; (c) Average serum concentration $(\mu \mathrm{M})$ of PDC and Dox at each time interval obtained from the LC/MS data. Data shown is mean \pm SD. 


\subsection{TNBC Tumor Growth Rate in a Subcutaneous Cell-Derived Xenograft Model}

Human breast cancer MDA-MB-231 cells were selected for establishing cell-derived xenograft (CDX) in female NOD-SCID mice. MDA-MB-231 cells are aggressive with high metastatic potential and belong to mesenchymal (M) TNBC subtype (Basal B) $[3,36,37]$. The gene expression profile for these cells is associated with stem cells and mesenchymal stem cell-specific markers. Breast tumor xenografts were established by subcutaneously injecting two million MDA-MB-231 cells in the right flank of mice. The subcutaneous xenografts, unlike the orthotopic xenografts, do not metastasize, however are still a popular model for studying antitumor efficacy [38]. Tumor growth was monitored by measuring the tumor size twice a week. As shown in Figure 3, the tumor volume reached $130.9 \pm 30 \mathrm{~mm}^{3}$ in 26 days. A high variation in volume of the xenograft tumors was observed, which is a characteristic of subcutaneous implanted xenografts [39]. On day 4 post-cell injection, tumors were observed by the naked eye growing on top of the mammary gland. The tumor volume increased gradually with a round to oval-shaped bump. Throughout the 26-day tumor growth period, the behavior and general appearance of mice remained normal.

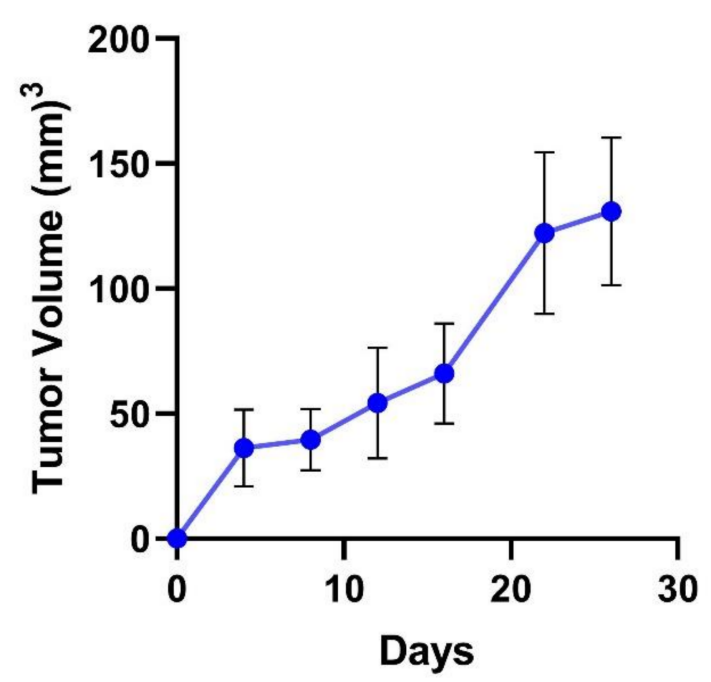

Figure 3. The growth curve of established tumors $(n=21$, mean $\pm \mathrm{SD})$ using direct subcutaneous injection of MDA-MB-231 cells (2 million in media and Matrigel, $100 \mu \mathrm{L}, 1: 1)$ into the right flank of female NOD-SCID mice (8-week-old).

\subsection{In Vivo Antitumor Effect of Peptide-Dox Conjugate}

After the tumor xenografts reached a volume of around $100-150 \mathrm{~mm}^{3}$, mice were randomized into three groups $(n=7)$, namely, saline (negative control), free doxorubicin (positive control), and hydrazone PDC. A low dose of $2.5 \mathrm{mg} / \mathrm{kg}$ Dox [33,40] or $2.5 \mathrm{mg} / \mathrm{kg}$ Dox equivalent for PDC was chosen to study the antitumor efficacy in vivo. Mice were intravenously administered treatment by tail vein every seventh day for six doses. Compared to the saline group, the PDC reduced tumor growth significantly (3.8 times) on day 35 after treatment, whereas the reduction of tumor growth after free Dox treatment was 2.5 times (Figure 4a), suggesting the PDC, at the same equivalent dose, was more potent than the free Dox.

In addition, the mice treated with PDC remained in overall good health condition, as evidenced by the general appearance, behavior, diet consumption, and body weight. On day 32 during the treatment period, there were no significant differences observed between the PDC and saline groups in the average body weight $(p>0.05)$ (Figure $4 b)$. However, the mice treated with Dox showed significant body weight loss (reduced by $11.2 \%$ ) compared to the PDC group. Twenty-four hours after the last treatment with PDC or free Dox, mice were euthanized. Mice treated with saline were euthanized on day 32 because of the tumor size per IACUC policy and the conditions for euthanasia. Tumor and other major tissues were collected and weighted for further analysis. The mice with PDC treatment exhibited a 
greater reduction (three times reduction compared to saline) of tumor weight compared to that of free Dox treated (two times reduction compared to saline) (Figure 4c).

(a)

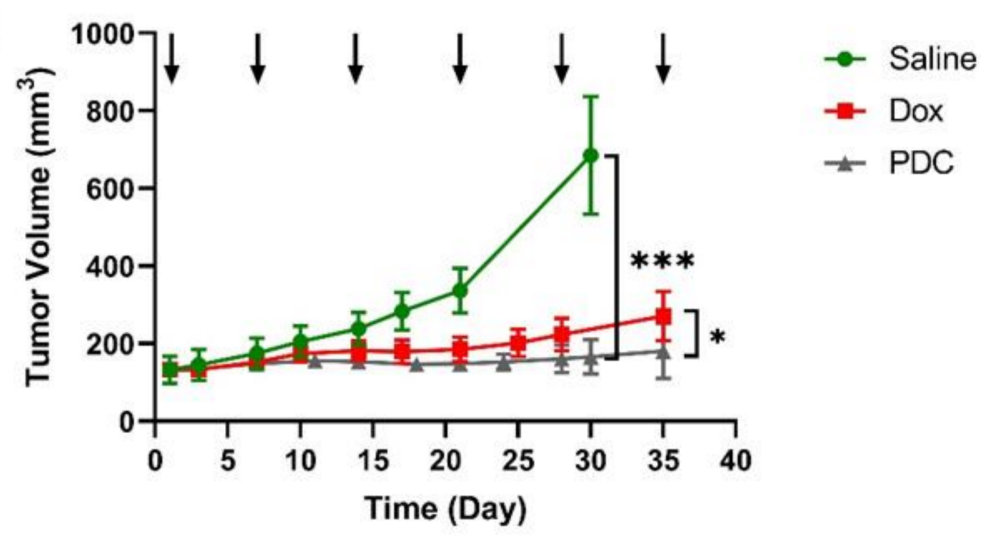

(b)

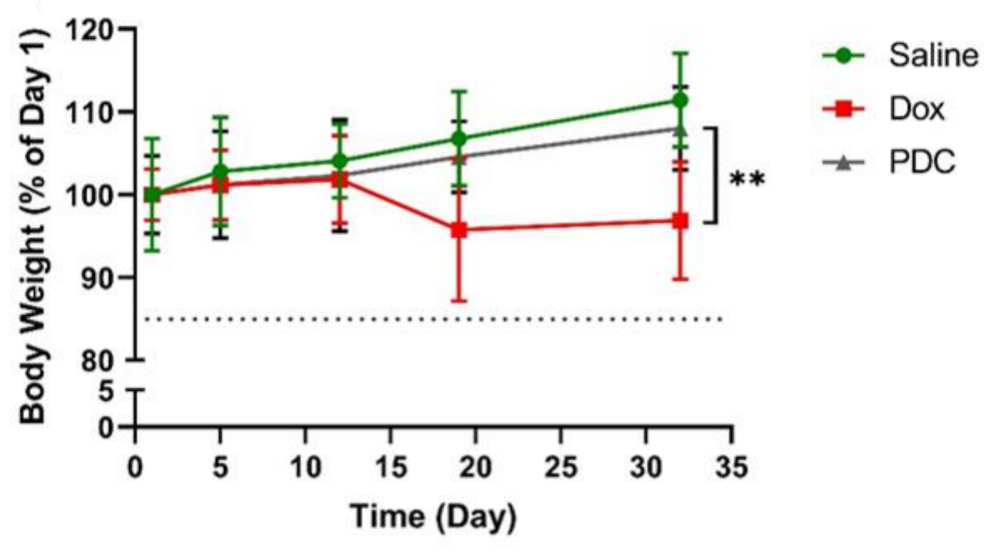

(c)
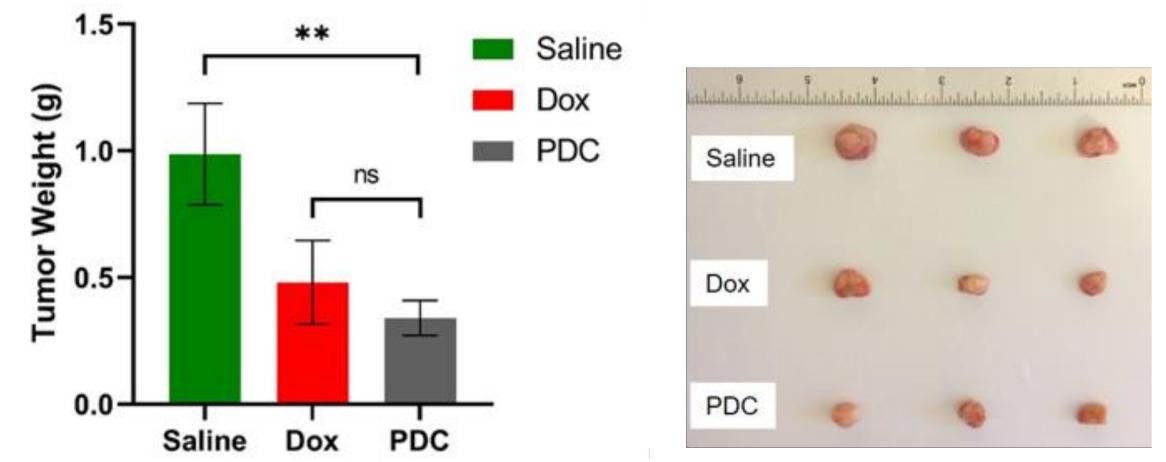

Figure 4. Effects of PDC on tumor growth using a mouse model of TNBC. NOD-SCID female mice bearing xenograft human MDA-MB-231 tumors were treated with PDC (2.5 mg Dox equiv. $/ \mathrm{kg})$, Dox $(2.5 \mathrm{mg} / \mathrm{kg})$, or saline $(0.9 \%$ normal saline). (a) Tumor volumes measured over the duration of treatment. The treatment regimen included six tail-vein injections administered weekly (as indicated by arrows). Results are presented as mean $\pm \mathrm{SD} ; n=7 ;{ }^{*} p<0.05,{ }^{* * *} p<0.001$, Student $t$-test and one-way ANOVA test (at day 30 or day 35); (b) Average body weight of mice for each treatment group. Results are presented as mean $\pm \mathrm{SD} ; n=7 ;{ }^{* *} p<0.01$, Student $t$-test and one-way ANOVA test (at day 32); (c) average tumor weight after mice were euthanized and tumors collected. Results are presented as mean $\pm \mathrm{SD} ; n=7 ;{ }^{* *} p<0.01$, ns non-significant, Student $t$-test and one-way ANOVA test. (RHS of c) representative images of the tumor xenografts collected from three groups. 


\subsection{In Vivo Tissue Biodistribution Study}

The tumor and five organ tissues (liver, spleen, kidneys, lungs, and heart) were collected and subjected to organic extraction to isolate and quantify PDC and/or its metabolites using LC/MS. At $24 \mathrm{~h}$ after the last treatment, only Dox was detected in all the samples. There were no PDC or other metabolites detected using the LC/MS method. In the PDC treated mice, the Dox content was much higher in tumor samples $(1.70 \pm 0.16 \mu \mathrm{g} / \mathrm{g})$ compared to other organs $(0.66-0.09 \mu \mathrm{g} / \mathrm{g})$ (Figure 5).

When comparing the PDC and Dox treatment groups, the Dox concentrations in isolated tumors of the PDC treated mice were significantly increased (1.4-fold more Dox). In contrast, in other tissues, Dox levels were lower in the PDC treated mice compared to the free Dox group, highlighting the targeted delivery of the conjugate to the tumor tissue. Mice treated with the conjugate showed significantly lower levels of Dox in liver (1.3 times), heart (1.4 times), lungs (1.9 times), and spleen (2.2 times) compared to mice treated with free Dox $(p<0.05)$. The levels in kidney were also lower (1.3 times) in PDC treated mice but not statistically significant. Notably, Dox levels were higher in the heart than in the kidney, spleen, and lungs for both the PDC and Dox treated mice. This is likely due to the cardiotoxicity of Dox as it tends to accumulate in the heart [41,42]. Higher levels of Dox in the heart compared to other organs were also observed by others after mice were treated with free Dox [43-45].

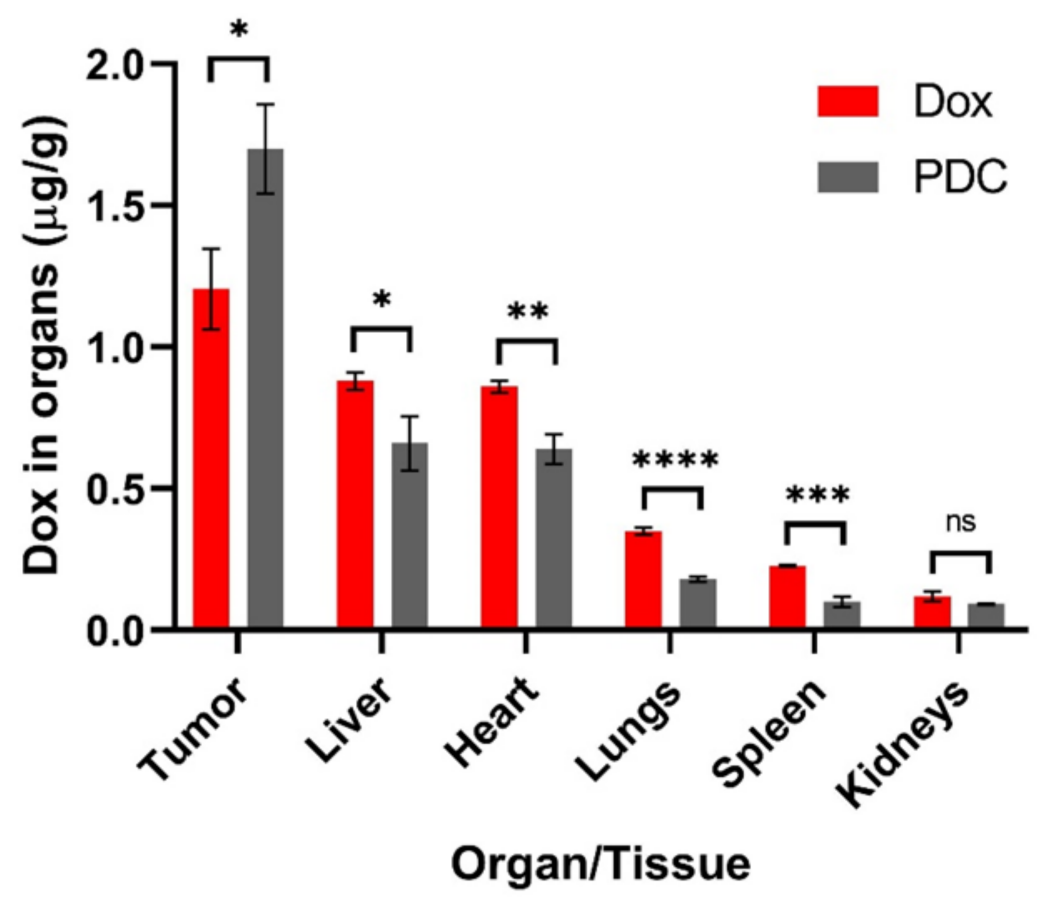

Figure 5. Biodistribution of Dox in tumor and other tissues at $24 \mathrm{~h}$ post injection (Dox or PDC). Data are presented as mean $\pm \mathrm{SD} ; n=3 ;^{*} p<0.05,{ }^{* *} p<0.01,{ }^{* * *} p<0.001,{ }^{* * * *} p<0.0001$, ns non-significant; Student $t$-test and one-way ANOVA were used. The significance level $(\alpha)$ was set at 0.05 .

\section{Discussion}

Peptide-drug conjugates represent a novel class of targeted drug delivery modalities in cancer therapy $[8,46,47]$. In a PDC, the targeting peptide and the linker play an important role in enhancing the efficacy of the drug. We used a linear 18-4 peptide that was engineered to bind breast cancer cells via the cell-surface $\mathrm{K} 1$ receptor $[23,28]$ The cellular uptake of peptide 18-4 and its PDC takes place via receptor-mediated endocytosis in breast cancer cells [25,48]. A PDC (Figure 1) using linear 18-4 peptide was synthesized to evaluate the specificity of the conjugate toward TNBC cells [29]. The conjugate showed specific toxicity toward the TNBC cells $\left(\mathrm{IC}_{50} 1.2-2.2 \mu \mathrm{M}\right)$ and was 9-fold less toxic to normal breast 
tissue-derived MCF-10A cells ( $\left.\mathrm{IC}_{50} 15.1 \mu \mathrm{M}\right)$. In comparison, Dox was equally toxic to both TNBC and normal cells. In this study, we demonstrate the in vivo specificity of the PDC for the tumor tissue. Using CDX mice models, we show significantly improved efficacy of PDC in reducing tumor volume compared to free Dox (Figure 4a). The results here validate the use of peptide 18-4 for targeting TNBC. We recently reported a cyclic analogue of 18-4 (N- to C-terminal cyclized WXEAAYQkFL) that targets TNBC 2-3 fold better than the linear 18-4 peptide [27]. A new PDC with the cyclic peptide could further enhance the efficacy of Dox for TNBC treatment. In addition to targeted drug delivery, peptide 18-4 and its cyclic analogue could be used to deliver drug-carrying micelles, siRNA, imaging agents, or diagnostics to TNBC cells. The use of the cyclic peptide for imaging of cells expressing $\mathrm{K} 1$ in intact tumor tissues was recently reported [49]. In addition, we previously reported that peptide 18-4 conjugated liposomes displayed superior antitumor activity compared to non-targeted Dox liposomes [32]. These studies highlight the use of peptide 18-4 and analogues for targeting novel cell surface receptor K1 in TNBC.

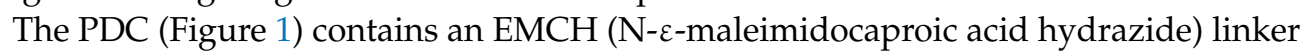
which has an acid-sensitive hydrazone and a maleimide group. Hydrazone was selected to facilitate the release of unmodified Dox at the cancer site, while maleimide allowed easy conjugation of the peptide via its cysteine thiol. A derivative of Dox with EMCH, called aldoxorubicin (Aldox), was used to form a protein-drug conjugate with endogenous albumin [50,51]. After systemic administration, the conjugate is formed between Aldox and the circulating albumin in the blood for site-selective delivery of Dox to the tumor. This protein-drug conjugate allowed greater doses $(3-4 \times)$ of Dox to be administered with minimal cardiotoxicity [47,52]. The only disadvantage of this approach is off-target toxicities due to possible reactions of Aldox with cysteine and lysine of other endogenous proteins. Regardless, Aldox continues to display promising results, including its current advanced phase clinical trials for the soft tissue sarcoma $[53,54]$.

The hydrazone group in the conjugate facilitates the release of the drug under mildly acidic conditions; however, it also makes it less stable. Previously, we found that when incubated with $25 \%$ human serum, the conjugate showed a half-life of $\approx 6 \mathrm{~h}$, mainly cleaving at the hydrazone bond, giving unmodified Dox and the peptide with the linker portion (Figure 1) [29]. After intravenous administration in mice, the PDC showed a half-life of around $1.7 \mathrm{~h}$ in blood (Figure 2c), which incidentally is much longer than the half-life of Dox (in min) [35]. The PDC led to an increase in the circulation time of the drug. Additionally, the amount of Dox in tumor tissue in PDC treated mice was significantly higher than the Dox treated mice (Figure 5). These results show higher specificity of PDC for the tumor tissue with less systemic toxicities compared to free Dox (Figure $4 \mathrm{~b}$ ). The usage of Dox is greatly limited by its cardiotoxic effects, ranging from occult changes in myocardial structure to severe cardiomyopathy and heart failure requiring cardiac transplantation [41]. Of note, the Dox levels in hearts after PDC treatment were much lower (1.4 times) compared to free Dox treatment group. The use of PDC may reduce the risk of cardiotoxicity without compromising its anti-tumor activities.

PDCs targeting different overexpressed receptors in cancer cells are being developed. TNBC has been a difficult breast cancer subtype to target mainly due to the heterogeneity of this cancer subtype and lack of clinically validated markers. Recently, an ADC sacituzumab govitecan (targeting cell-surface Trop-2) was approved for the treatment of metastatic TNBC [12-14]. Trop-2 is a glycoprotein present in elevated amounts on the surface of cancer cells in solid tumors affecting multiple cancer signaling pathways [13]. PDC targeting other overexpressed receptors such as EphA2 [15,17,19], LRP-1 [20,21], and GnRH [55] are under development for metastatic breast cancer. The PDC (Figure 1) studied here targets cell-surface K1 receptor. Keratins are cytoskeleton proteins; however, the cell-surface presence of keratins is found in several cancer cells, including breast (K1), neuroblastoma (K1), and colon (keratin 8) cancer cells [23-25,56], and these proteins are linked to tumor metastases. The promising results with the PDC warrant further investigation of K1 targeting conjugates as a new modality for targeted TNBC treatment. 


\section{Conclusions}

We show that the PDC with K1 targeting peptide and acid-sensitive hydrazone linker is more efficacious and less systemically toxic compared to free Dox in mice with TNBC xenografts. The peptide and linker chemistry used here can be applied to prepare new PDCs with different chemotherapeutic agents (such as paclitaxel and exatecan) as potential therapeutics for TNBC. The PDC increases the circulation time for the drug in blood compared to free Dox, along with increased concentration of the drug in tumor. The specificity and lower systemic toxicity of the PDC were demonstrated by the lower levels of Dox in non-tumor tissues (such as liver, heart, lung, and spleen) in comparison to free Dox. The study demonstrates the feasibility of achieving a better therapeutic option for TNBC using PDC that target a novel receptor K1.

Supplementary Materials: The following are available online at https:/ /www.mdpi.com/article/10 .3390/pharmaceutics13050661/s1, Figure S1. Chromatogram for the peptide-Dox conjugate (PDC) obtained after injection of pure PDC ( $280 \mu \mathrm{M}, 20 \mu \mathrm{L})$ into the LC/MS running with a reversed-phase analytical column $(4.6 \mathrm{~mm} \times 250 \mathrm{~mm}, 5 \mu \mathrm{m})$ with an acetonitrile/water (with $0.05 \%$ formic acid) gradient as shown; Figure S2. UV-vis spectra for Dox, Aldox, peptide, and PDC at $\sim 200 \mu \mathrm{M}$ concentration using UV/Vis spectrophotometer UV-2600/2700 (Shimadzu, USA); Figure S3. Chromatogram showing plasma concentration of Dox after administration of Dox in female 8-9 week-old NOD-SCID mice; Table S1. Concentration of PDC and Dox in blood from mice $(n=3)$ after intravenous injection.

Author Contributions: K.K. and A.S. designed the study, analyzed the results, and wrote the manuscript. A.S. performed all the experiments. S.C. provided expert advice with breast cancer biology and mice experiments. S.Y. provided expert advice for mice experiments. All authors have read and agreed to the published version of the manuscript.

Funding: This work was supported by the National Cancer Institute of the National Institutes of Health Award Number R15CA208656 (to K.K. and S.C.). S.Y. received salary support by the career development K08CA179084 award from the National Institutes of Health.

Institutional Review Board Statement: The experiments with mice were approved by the Chapman University Institutional Animal Care and Use Committee (IACUC) with protocol number 1617A008 (approval period 16 May 2017-15 May 2020) and protocol number 2020-1148 (20 May 2020-20 May 2023). The protocols were in compliance with applicable federal and state regulations and Chapman University policies regarding the ethics and welfare of animal subjects used.

Informed Consent Statement: Not applicable.

Data Availability Statement: Not applicable.

Acknowledgments: We would like to acknowledge the Core laboratory at the Chapman University School of Pharmacy for the facilities. The authors thank Basir Syed for assistance with LCMS, and the vivarium staff, including David Lopez and Vanessa Salvary, for help with the in vivo procedures.

Conflicts of Interest: The authors declare no conflict of interest.

\section{Abbreviations}

\begin{tabular}{|c|c|}
\hline Aldox & aldoxorubicin \\
\hline $\mathrm{ADC}$ & antibody-drug conjugate \\
\hline ANOVA & analysis of variance \\
\hline CDX & cell-derived xenograft \\
\hline Dau & daunorubicin \\
\hline Dox & doxorubicin \\
\hline EphA2 & erythropoietin-producing hepatocellular receptor A2 \\
\hline $\mathrm{GnRH}$ & gonadotropin-releasing hormone \\
\hline K1 & keratin 1 \\
\hline $\mathrm{LC} / \mathrm{MS}$ & liquid chromatography-mass spectrometry \\
\hline LRP1 & LDL receptor-related protein 1 \\
\hline
\end{tabular}




$\begin{array}{ll}\text { NOD-SCID } & \text { nonobese diabetic-severe combined immunodeficiency } \\ \text { PARP } & \text { poly-ADP ribose-polymerase } \\ \text { pCR } & \text { pathological complete response } \\ \text { PDC } & \text { peptide-drug conjugate or peptide-doxorubicin conjugate } \\ \text { RP-HPLC } & \text { reversed-phase high performance liquid chromatography } \\ \text { TNBC } & \text { triple-negative breast cancer } \\ \text { Trop-2 } & \text { trophoblast cell-surface antigen } 2\end{array}$

\section{References}

1. Bianchini, G.; Balko, J.M.; Mayer, I.A.; Sanders, M.E.; Gianni, L. Triple-negative breast cancer: Challenges and opportunities of a heterogeneous disease. Nat. Rev. Clin. Oncol. 2016, 13, 674-690. [CrossRef]

2. Palma, G.; Frasci, G.; Chirico, A.; Esposito, E.; Siani, C.; Saturnino, C.; Arra, C.; Ciliberto, G.; Giordano, A.; D’Aiuto, M. Triple negative breast cancer: Looking for the missing link between biology and treatments. Oncotarget 2015, 6, 26560-26574. [CrossRef] [PubMed]

3. Lehmann, B.D.; Jovanovic, B.; Chen, X.; Estrada, M.V.; Johnson, K.N.; Shyr, Y.; Moses, H.L.; Sanders, M.E.; Pietenpol, J.A. Refinement of Triple-Negative Breast Cancer Molecular Subtypes: Implications for Neoadjuvant Chemotherapy Selection. PLoS ONE 2016, 11, e0157368. [CrossRef]

4. Lyons, T.G. Targeted Therapies for Triple-Negative Breast Cancer. Curr. Treat. Options Oncol. 2019, 20, 82. [CrossRef]

5. Gotwals, P.; Cameron, S.; Cipolletta, D.; Cremasco, V.; Crystal, A.; Hewes, B.; Mueller, B.; Quaratino, S.; Sabatos-Peyton, C.; Petruzzelli, L.; et al. Prospects for combining targeted and conventional cancer therapy with immunotherapy. Nat. Rev. Cancer 2017, 17, 286-301. [CrossRef]

6. Mehta, R.S. Dose-dense and/or metronomic schedules of specific chemotherapies consolidate the chemosensitivity of triplenegative breast cancer: A step toward reversing triple-negative paradox. J. Clin. Oncol. 2008, 26, 3286-3288. [CrossRef] [PubMed]

7. DeMichele, A.; Yee, D.; Esserman, L. Mechanisms of Resistance to Neoadjuvant Chemotherapy in Breast Cancer. N. Engl. J. Med. 2017, 377, 2287-2289. [CrossRef] [PubMed]

8. Alas, M.; Saghaeidehkordi, A.; Kaur, K. Peptide-Drug Conjugates with Different Linkers for Cancer Therapy. J. Med. Chem. 2021, 64, 216-232. [CrossRef]

9. Chau, C.H.; Steeg, P.S.; Figg, W.D. Antibody-drug conjugates for cancer. Lancet 2019, 394, 793-804. [CrossRef]

10. Mitra, A.K.; Agrahari, V.; Mandal, A.; Cholkar, K.; Natarajan, C.; Shah, S.; Joseph, M.; Trinh, H.M.; Vaishya, R.; Yang, X.; et al. Novel delivery approaches for cancer therapeutics. J. Control. Release 2015, 219, 248-268. [CrossRef] [PubMed]

11. Bargh, J.D.; Isidro-Llobet, A.; Parker, J.S.; Spring, D.R. Cleavable linkers in antibody-drug conjugates. Chem. Soc. Rev. 2019, 48, 4361-4374. [CrossRef] [PubMed]

12. Bardia, A.; Mayer, I.A.; Vahdat, L.T.; Tolaney, S.M.; Isakoff, S.J.; Diamond, J.R.; O'Shaughnessy, J.; Moroose, R.L.; Santin, A.D.; Abramson, V.G.; et al. Sacituzumab govitecan-hziy in refractory metastatic triple-negative breast cancer. N. Engl. J. Med. 2019, 380, 741-751. [CrossRef] [PubMed]

13. Goldenberg, D.M.; Cardillo, T.M.; Govindan, S.V.; Rossi, E.A.; Sharkey, R.M. Trop-2 is a novel target for solid cancer therapy with sacituzumab govitecan (IMMU-132), an antibody-drug conjugate (ADC). Oncotarget 2015, 6, 22496-22512. [CrossRef]

14. Sahota, S.; Vahdat, L.T. Sacituzumab govitecan: An antibody-drug conjugate. Expert Opin. Biol. Ther. 2017, 17, 1027-1031. [CrossRef]

15. Ireton, R.C.; Chen, J. EphA2 receptor tyrosine kinase as a promising target for cancer therapeutics. Curr. Cancer Drug Targets 2005, 5, 149-157. [CrossRef]

16. Walker-Daniels, J.; Hess, A.R.; Hendrix, M.J.; Kinch, M.S. Differential regulation of EphA2 in normal and malignant cells. Am. J. Pathol. 2003, 162, 1037-1042. [CrossRef]

17. Mudd, G.E.; Brown, A.; Chen, L.; van Rietschoten, K.; Watcham, S.; Teufel, D.P.; Pavan, S.; Lani, R.; Huxley, P.; Bennett, G.S. Identification and optimization of EphA2-selective bicycles for the delivery of cytotoxic payloads. J. Med. Chem. 2020, 63, 4107-4116. [CrossRef] [PubMed]

18. Quinn, B.A.; Wang, S.; Barile, E.; Das, S.K.; Emdad, L.; Sarkar, D.; De, S.K.; Morvaridi, S.K.; Stebbins, J.L.; Pandol, S.J.; et al. Therapy of pancreatic cancer via an EphA2 receptor-targeted delivery of gemcitabine. Oncotarget 2016, 7, 17103-17110. [CrossRef]

19. Salem, A.F.; Wang, S.; Billet, S.; Chen, J.F.; Udompholkul, P.; Gambini, L.; Baggio, C.; Tseng, H.R.; Posadas, E.M.; Bhowmick, N.A.; et al. Reduction of Circulating Cancer Cells and Metastases in Breast-Cancer Models by a Potent EphA2-Agonistic Peptide-Drug Conjugate. J. Med. Chem. 2018, 61, 2052-2061. [CrossRef]

20. Kumthekar, P.; Tang, S.C.; Brenner, A.J.; Kesari, S.; Piccioni, D.E.; Anders, C.; Carrillo, J.; Chalasani, P.; Kabos, P.; Puhalla, S.; et al. ANG1005, a Brain-Penetrating Peptide-Drug Conjugate, Shows Activity in Patients with Breast Cancer with Leptomeningeal Carcinomatosis and Recurrent Brain Metastases. Clin. Cancer Res. 2020, 26, 2789-2799. [CrossRef]

21. Kurzrock, R.; Gabrail, N.; Chandhasin, C.; Moulder, S.; Smith, C.; Brenner, A.; Sankhala, K.; Mita, A.; Elian, K.; Bouchard, D.; et al. Safety, pharmacokinetics, and activity of GRN1005, a novel conjugate of angiopep-2, a peptide facilitating brain penetration, and paclitaxel, in patients with advanced solid tumors. Mol. Cancer Ther. 2012, 11, 308-316. [CrossRef] [PubMed] 
22. O'Sullivan, C.C.; Lindenberg, M.; Bryla, C.; Patronas, N.; Peer, C.J.; Amiri-Kordestani, L.; Davarpanah, N.; Gonzalez, E.M.; Burotto, M.; Choyke, P.; et al. ANG1005 for breast cancer brain metastases: Correlation between (18)F-FLT-PET after first cycle and MRI in response assessment. Breast Cancer Res. Treat. 2016, 160, 51-59. [CrossRef]

23. Chuang, N.N.; Huang, C.C. Interaction of integrin beta1 with cytokeratin 1 in neuroblastoma NMB7 cells. Biochem. Soc. Trans. 2007, 35, 1292. [CrossRef] [PubMed]

24. Doljak, B.; Obermajer, N.; Jamnik, P.; Kos, J. Monoclonal antibody to cytokeratin VKIALEVEIATY sequence motif reduces plasminogen activation in breast tumour cells. Cancer Lett. 2008, 267, 75-84. [CrossRef] [PubMed]

25. Soudy, R.; Etayash, H.; Bahadorani, K.; Lavasanifar, A.; Kaur, K. Breast Cancer Targeting Peptide Binds Keratin 1: A New Molecular Marker for Targeted Drug Delivery to Breast Cancer. Mol. Pharm. 2017, 14, 593-604. [CrossRef]

26. Collard, C.D.; Montalto, M.C.; Reenstra, W.R.; Buras, J.A.; Stahl, G.L. Endothelial oxidative stress activates the lectin complement pathway: Role of cytokeratin 1. Am. J. Pathol. 2001, 159, 1045-1054. [CrossRef]

27. Raghuwanshi, Y.; Etayash, H.; Soudy, R.; Paiva, I.; Lavasanifar, A.; Kaur, K. Proteolytically Stable Cyclic Decapeptide for Breast Cancer Cell Targeting. J. Med. Chem. 2017, 60, 4893-4903. [CrossRef]

28. Soudy, R.; Chen, C.; Kaur, K. Novel peptide-doxorubucin conjugates for targeting breast cancer cells including the multidrug resistant cells. J. Med. Chem. 2013, 56, 7564-7573. [CrossRef]

29. Ziaei, E.; Saghaeidehkordi, A.; Dill, C.; Maslennikov, I.; Chen, S.; Kaur, K. Targeting Triple Negative Breast Cancer Cells with Novel Cytotoxic Peptide-Doxorubicin Conjugates. Bioconjug. Chem. 2019, 30, 3098-3106. [CrossRef]

30. Banerjee, S.; Mazumdar, S. Electrospray ionization mass spectrometry: A technique to access the information beyond the molecular weight of the analyte. Int. J. Anal. Chem. 2012, 2012, 282574. [CrossRef]

31. Lewis Phillips, G.D.; Li, G.; Dugger, D.L.; Crocker, L.M.; Parsons, K.L.; Mai, E.; Blattler, W.A.; Lambert, J.M.; Chari, R.V.; Lutz, R.J.; et al. Targeting HER2-positive breast cancer with trastuzumab-DM1, an antibody-cytotoxic drug conjugate. Cancer Res. 2008, 68, 9280-9290. [CrossRef]

32. Binkhathlan, Z.; Shayeganpour, A.; Brocks, D.R.; Lavasanifar, A. Encapsulation of P-glycoprotein inhibitors by polymeric micelles can reduce their pharmacokinetic interactions with doxorubicin. Eur. J. Pharm. Biopharm. 2012, 81, 142-148. [CrossRef]

33. Shahin, M.; Soudy, R.; Aliabadi, H.M.; Kneteman, N.; Kaur, K.; Lavasanifar, A. Engineered breast tumor targeting peptide ligand modified liposomal doxorubicin and the effect of peptide density on anticancer activity. Biomaterials 2013, 34, 4089-4097. [CrossRef]

34. Kai, M.; Kanaya, N.; Wu, S.V.; Mendez, C.; Nguyen, D.; Luu, T.; Chen, S. Targeting breast cancer stem cells in triple-negative breast cancer using a combination of LBH589 and salinomycin. Breast Cancer Res. Treat. 2015, 151, 281-294. [CrossRef] [PubMed]

35. Yousefpour, P.; Ahn, L.; Tewksbury, J.; Saha, S.; Costa, S.A.; Bellucci, J.J.; Li, X.; Chilkoti, A. Conjugate of Doxorubicin to Albumin-Binding Peptide Outperforms Aldoxorubicin. Small 2019, 15, e1804452. [CrossRef]

36. Lehmann, B.D.; Bauer, J.A.; Chen, X.; Sanders, M.E.; Chakravarthy, A.B.; Shyr, Y.; Pietenpol, J.A. Identification of human triple-negative breast cancer subtypes and preclinical models for selection of targeted therapies. J. Clin. Investig. 2011, 121, 2750-2767. [CrossRef] [PubMed]

37. Neve, R.M.; Chin, K.; Fridlyand, J.; Yeh, J.; Baehner, F.L.; Fevr, T.; Clark, L.; Bayani, N.; Coppe, J.P.; Tong, F.; et al. A collection of breast cancer cell lines for the study of functionally distinct cancer subtypes. Cancer Cell 2006, 10, 515-527. [CrossRef] [PubMed]

38. Hoffman, R.M. Patient-derived orthotopic xenografts: Better mimic of metastasis than subcutaneous xenografts. Nat. Rev. Cancer 2015, 15, 451-452. [CrossRef] [PubMed]

39. Zhang, Y.; Zhang, G.L.; Sun, X.; Cao, K.X.; Ma, C.; Nan, N.; Yang, G.W.; Yu, M.W.; Wang, X.M. Establishment of a murine breast tumor model by subcutaneous or orthotopic implantation. Oncol. Lett. 2018, 15, 6233-6240. [CrossRef]

40. Bandyopadhyay, A.; Wang, L.; Agyin, J.; Tang, Y.; Lin, S.; Yeh, I.T.; De, K.; Sun, L.Z. Doxorubicin in combination with a small TGFbeta inhibitor: A potential novel therapy for metastatic breast cancer in mouse models. PLoS ONE 2010, 5, e10365. [CrossRef] [PubMed]

41. Sawicki, K.T.; Sala, V.; Prever, L.; Hirsch, E.; Ardehali, H.; Ghigo, A. Preventing and Treating Anthracycline Cardiotoxicity: New Insights. Annu. Rev. Pharmacol. Toxicol. 2021, 61, 309-332. [CrossRef]

42. Wenningmann, N.; Knapp, M.; Ande, A.; Vaidya, T.R.; Ait-Oudhia, S. Insights into Doxorubicin-induced Cardiotoxicity: Molecular Mechanisms, Preventive Strategies, and Early Monitoring. Mol. Pharmacol. 2019, 96, 219-232. [CrossRef]

43. Argenziano, M.; Gigliotti, C.L.; Clemente, N.; Boggio, E.; Ferrara, B.; Trotta, F.; Pizzimenti, S.; Barrera, G.; Boldorini, R.; Bessone, F.; et al. Improvement in the Anti-Tumor Efficacy of Doxorubicin Nanosponges in In Vitro and in Mice Bearing Breast Tumor Models. Cancers 2020, 12, 162. [CrossRef] [PubMed]

44. Sheng, Y.; You, Y.; Chen, Y. Dual-targeting hybrid peptide-conjugated doxorubicin for drug resistance reversal in breast cancer. Int. J. Pharm. 2016, 512, 1-13. [CrossRef]

45. Zhong, Q.; Bielski, E.R.; Rodrigues, L.S.; Brown, M.R.; Reineke, J.J.; da Rocha, S.R. Conjugation to Poly(amidoamine) Dendrimers and Pulmonary Delivery Reduce Cardiac Accumulation and Enhance Antitumor Activity of Doxorubicin in Lung Metastasis. Mol. Pharm. 2016, 13, 2363-2375. [CrossRef]

46. Vrettos, E.I.; Mezo, G.; Tzakos, A.G. On the design principles of peptide-drug conjugates for targeted drug delivery to the malignant tumor site. Beilstein J. Org. Chem. 2018, 14, 930-954. [CrossRef]

47. Wang, Y.; Cheetham, A.G.; Angacian, G.; Su, H.; Xie, L.; Cui, H. Peptide-drug conjugates as effective prodrug strategies for targeted delivery. Adv. Drug Deliv. Rev. 2017, 110-111, 112-126. [CrossRef] 
48. Soudy, R.; Gill, A.; Sprules, T.; Lavasanifar, A.; Kaur, K. Proteolytically stable cancer targeting peptides with high affinity for breast cancer cells. J. Med. Chem. 2011, 54, 7523-7534. [CrossRef] [PubMed]

49. Subiros-Funosas, R.; Ho, V.C.L.; Barth, N.D.; Mendive-Tapia, L.; Pappalardo, M.; Barril, X.; Ma, R.; Zhang, C.-B.; Bin-Zhi, Q.; Miquel, S.; et al. Fluorogenic Trp(redBODIPY) cyclopeptide targeting keratin 1 for imaging of aggressive carcinomas. Chem. Sci. 2020, 11, 1368. [CrossRef]

50. Di Stefano, G.; Lanza, M.; Kratz, F.; Merina, L.; Fiume, L. A novel method for coupling doxorubicin to lactosaminated human albumin by an acid sensitive hydrazone bond: Synthesis, characterization and preliminary biological properties of the conjugate. Eur. J. Pharm. Sci. 2004, 23, 393-397. [CrossRef] [PubMed]

51. Kratz, F. DOXO-EMCH (INNO-206): The first albumin-binding prodrug of doxorubicin to enter clinical trials. Expert Opin. Investig. Drugs 2007, 16, 855-866. [CrossRef] [PubMed]

52. Kratz, F.; Warnecke, A.; Schmid, B.; Chung, D.E.; Gitzel, M. Prodrugs of anthracyclines in cancer chemotherapy. Curr. Med. Chem. 2006, 13, 477-523. [CrossRef] [PubMed]

53. Chawla, S.P.; Papai, Z.; Mukhametshina, G.; Sankhala, K.; Vasylyev, L.; Fedenko, A.; Khamly, K.; Ganjoo, K.; Nagarkar, R.; Wieland, S.; et al. First-line aldoxorubicin vs doxorubicin in metastatic or locally advanced unresectable soft-tissue sarcoma: A phase $2 \mathrm{~b}$ randomized clinical trial. JAMA Oncol. 2015, 1, 1272-1280. [CrossRef]

54. Gong, J.; Yan, J.; Forscher, C.; Hendifar, A. Aldoxorubicin: A tumor-targeted doxorubicin conjugate for relapsed or refractory soft tissue sarcomas. Drug Des. Dev. Ther. 2018, 12, 777-786. [CrossRef] [PubMed]

55. Randelovic, I.; Schuster, S.; Kapuvari, B.; Fossati, G.; Steinkuhler, C.; Mezo, G.; Tovari, J. Improved in vivo anti-tumor and anti-metastatic effect of GnRH-III-daunorubicin analogs on colorectal and breast carcinoma bearing mice. Int. J. Mol. Sci. 2019, 20, 4763. [CrossRef] [PubMed]

56. Ditzel, H.J.; Garrigues, U.; Andersen, C.B.; Larsen, M.K.; Garrigues, H.J.; Svejgaard, A.; Hellstrom, I.; Hellstrom, K.E.; Jensenius, J.C. Modified cytokeratins expressed on the surface of carcinoma cells undergo endocytosis upon binding of human monoclonal antibody and its recombinant Fab fragment. Proc. Natl. Acad. Sci. USA 1997, 94, 8110-8115. [CrossRef] 